\title{
Employee Welfare Motive at Sar World Wide Logistics Pvt Ltd
}

\section{S. Praveen Kumar, J. Pavithra, S. Krupa Sharon Nishitha}

\begin{abstract}
Representative welfare incorporates everything, for example, offices, advantages and administration that a worker gives or does to guarantee solace of the representatives. Representative welfare implies anything accomplished for the solace and improvement off the workers well beyond the wages paid which isn't important of the organization. Great welfare rouses representatives and guarantee expanded profitability. The different welfare offices give by the organization will quick effect on the wellbeing, physically and mental effectiveness, readiness, spirit, security and by and large proficiency of laborer and subsequently adding to the higher efficiency. The fundamental reason for worker welfare is to enhance the life of representatives and to stay with them upbeat in the. They realize that they add to the association when they are sensibly free from stress and they feel that when they are in a difficult situation. Welfare measures might be both statutory and non-statutory. Laws require the businesses to degree the specific advantages to workers.
\end{abstract}

Keywords: Employee welfare, Higher productivity, Mental efficiency

\section{INTRODUCTION}

Specialist welfare fuses everything, for instance, workplaces, points of interest and organization that a delegate gives or does to ensure comfort of the agents. Incredible welfare drives agents and certification extended proficiency.

Agent welfare is a term including various organizations, favorable circumstances and workplaces offered to laborers by the organizations. The welfare assessments need not be cash related yet rather in any kind. This fuses things, for instance, stipends, lodging, transportation, helpful assurance and sustenance[1],[3],[5]. Agent welfare in like manner fuses checking of working conditions, creation of mechanical concordance through establishment for prosperity, present day relations and security against affliction, fortuitous and joblessness of the workers and their families. Through such liberal preferred position the delegate maker like worth living for laborers. Welfare fuses whatever is cultivated for the comfort and improvement of laborers and is given well past the wages.

Revised Manuscript Received on July 22, 2019.

Dr. S. Praveen Kumar, Department of MBA, Bharath Institute of Higher Education and Research, Chennai, India. Email: praveenkumar.mba@bharathuniv.ac.in

Ms. J. Pavithra, Department of MBA, Bharath Institute of Higher Education and Research, Chennai, India.

Email: pavithralect@yahoo.com

S. Krupa Sharon Nishitha, Department of MBA, Bharath Institute of Higher Education and Research, Chennai, India

Email: krupasharon1197@gmail.com
Welfare helps in keeping the certainty and motivation of the laborers high so as hold the delegate high so as to hold the agents for longer term. The welfare assessments need not be in money related terms just but instead in any kind [2],[4],[6]. Delegate welfare consolidates checking of working conditions, creation of present day concordance through establishment for prosperity, mechanical relations and insurance against illness, disaster and joblessness for the workers and their families. [7], [9] ,[11]

\section{A. Types of employee welfare}

Intramural: These are provided within the organization like

- Canteen

- Rest rooms

- Crèches

- Uniforms

- Drinking water facility

- First aid appliance

- Facilities for sitting

- Lighting

- Latrines and urinals

\section{SIGNIFICANCE OF THE STUDY}

To realize the fulfillment level of workers towards representative welfare.

2. To discover the offices give to the worker by the organization.

3. To realize the representative are disappointed will assist them with getting spur.

4. To discover the welfare offices like lodging, therapeutic, kids training and so on help to improve the family life of representative.

\section{RESEARCH METHODOLOGY}

Research methodology may be understood as a science of studying how the research has been done scientifically. It is way to systematically solve the research problem. Here, we study and analyse the various steps that are generally adopted by researcher in studying his research problems. [8], [10],[12]

\section{A. Statistical Tool}

An important decision that has to be taken is adopting the sampling technique is about the size of the sample. Size of the sample means the number of sampling.

$$
\text { Sample size }=\left[\mathbf{Z}^{2} * \mathbf{P} * \mathbf{Q}\right] / \mathbf{E}^{2}
$$

\section{Chi Square Test}

A chi squared test, also referred to as test, is any 


\section{Employee Welfare Motive at Sar World Wide Logistics Pvt Ltd}

statistical hypothesis tests where in the sampling distribution of the statistic is a chi square distribution when the null hypothesis is true.

Chi square test is often constructed from a sum of squared errors, or through the sample variance. Test statistics that follows a chi-squared distribution arise from an assumption of independent normally distributed data, which is valid in many cases due to the central limit theorem. [13], [15],[17]

\section{Chi square test $=[\mathrm{O}-\mathrm{E}]^{2} / \mathrm{E}$}

Table 1 - Employee satisfaction level of canteen facility of the company

\begin{tabular}{|l|l|l|l|}
\hline S.NO & PARTICULARS & RESPONDENTS & PERCENTAGE \\
\hline 1 & HIGHLY SATISFACTIED & 24 & $15 \%$ \\
\hline 2 & SATISFACTIED & 60 & $37 \%$ \\
\hline 3 & NEUTRAL & 39 & $24 \%$ \\
\hline 4 & DISSATISFACTIED & 36 & $22 \%$ \\
\hline 5 & HIGHLY DISSATISFACTIED & 04 & $2 \%$ \\
\hline & TOTAL & 163 & $100 \%$ \\
\hline
\end{tabular}

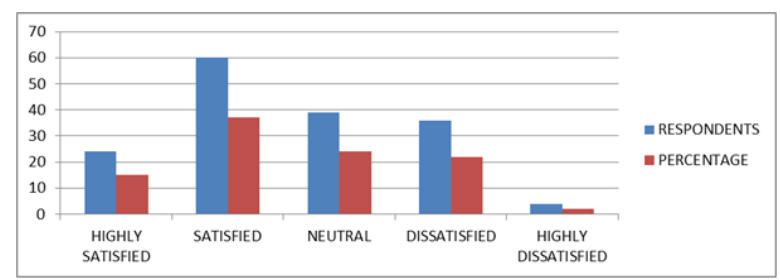

Figure 1 - Employee satisfaction level of canteen facility of the company

\section{Inference -}

From the above table and chart it clearly show that $15 \%$ of respondents have fully satisfied of his canteen facility of the company and $37 \%$ of respondents have satisfied of his canteen facility of the company and $24 \%$ of respondents have dissatisfied of his canteen facility of the company and $22 \%$ of respondents have dissatisfied of his canteen facility of the company and $2 \%$ of the respondents have highly dissatisfied of his canteen facility of the company.

Table 2 - Perceptions towards overtime allowances by the company

\begin{tabular}{|l|l|l|l|}
\hline S.NO & PARTICULARS & RESPONDENTS & PERCENTAGE \\
\hline 1 & HIGHLY SATISFACTIED & 13 & $8 \%$ \\
\hline 2 & SATISFACTIED & 48 & $30 \%$ \\
\hline 3 & NEUTRAL & 48 & $29 \%$ \\
\hline 4 & DISSATISFACTIED & 47 & $29 \%$ \\
\hline 5 & HIGHLY DISSATISFACTIED & 07 & $4 \%$ \\
\hline & TOTAL & 163 & $100 \%$ \\
\hline
\end{tabular}

Figure 2 - Perceptions towards overtime allowances by the company

\section{Inference-}

From the above table and chart it clearly show that $8 \%$ of respondents have fully satisfied of overtime allowances of the company and $30 \%$ of respondents have satisfied of overtime allowances of the company and $29 \%$ of respondents have dissatisfied of his overtime allowances of the company and $29 \%$ of respondents have dissatisfied of his canteen facility of the company and $4 \%$ of the respondents have highly dissatisfied overtime allowances of the company.

Table - 3 Employee welfare activities of the company give feeling of safety

\begin{tabular}{|l|l|l|l|}
\hline S.NO & PARTICULARS & RESPONDENTS & PERCENTAGE \\
\hline 1 & YES & 114 & $70 \%$ \\
\hline 2 & NO & 49 & $30 \%$ \\
\hline & TOTAL & 163 & $100 \%$ \\
\hline
\end{tabular}

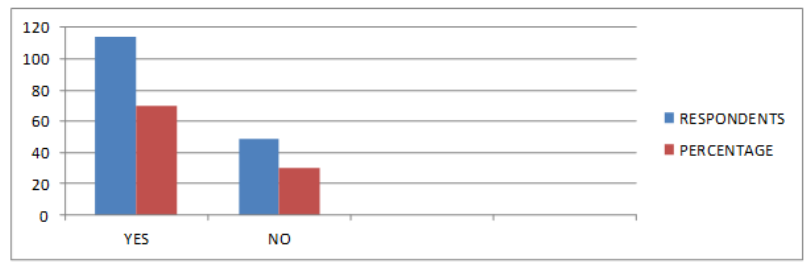

Figure - 3 Employee welfare activities of the company give feeling of safety

\section{Inference-}

From the above table and chart it clearly show that $70 \%$ of respondents have told the company has full safety and $30 \%$ of respondents have told the company has not feeling of safety.

\section{Chi-square}

Table -4 The number of years of employees tenure of the company

\begin{tabular}{|l|l|}
\hline 94 & 64 \\
\hline 04 & 01 \\
\hline
\end{tabular}

1. Null hypothesis : there is no significance difference between the number of years of employee tenure of the company 
2. Alternative hypothesis: there is significance between the number of years of employee tenure of the company.

\begin{tabular}{|l|l|l|}
\hline 94 & 64 & 158 \\
\hline 04 & 01 & 05 \\
\hline 98 & 65 & 163 \\
\hline
\end{tabular}

\begin{tabular}{|l|l|l|l|l|}
\hline $\mathrm{O}$ & E=R.T*C.T/G.T & \multicolumn{1}{|c|}{$[\mathrm{O}-\mathrm{E}]$} & \multicolumn{1}{|c|}{$[\mathrm{O}-\mathrm{E}]^{2}$} & {$[\mathrm{O}-\mathrm{E}]^{2} / \mathrm{E}$} \\
\hline 94 & $158 * 98 / 163=94.99$ & -0.99 & 0.9801 & 0.010 \\
\hline 64 & $158 * 65 / 163=63.006$ & 0.99 & 0.9801 & 0.015 \\
\hline 04 & $05 * 98 / 163=3.006$ & 0.99 & 0.9801 & 0.32 \\
\hline 01 & $05 * 65 / 163=1.99$ & 0.99 & 0.9801 & 0.49 \\
\hline & \multicolumn{4}{|l}{} \\
\hline
\end{tabular}

$\mathrm{X}=[\mathrm{O}-\mathrm{E}]^{2} / \mathrm{E}$

Calculated value $=0.835$

Degree of freedom:

$$
\begin{aligned}
& \mathrm{V}=[\mathrm{r}-1][\mathrm{c}-1] \\
& \mathrm{V}=[2-1][2-1] \\
& \mathrm{V}=1
\end{aligned}
$$

Table value $=3.84($ constant value $)$

Calculated value $<$ Table value

It is not significant

Table - 5 The opinion of employees about the medical and first aid facility

\begin{tabular}{|l|l|}
\hline 63 & 63 \\
\hline 31 & 06 \\
\hline
\end{tabular}

1. Null hypothesis : there is no significance difference between the opinion of employee about the medical and first aid facility

2. Alternative hypothesis: there is significance between the opinion of employee about the medical and first aid facility.

\begin{tabular}{|l|l|l|}
\hline 63 & 63 & 126 \\
\hline 31 & 06 & 37 \\
\hline 94 & 69 & 163 \\
\hline
\end{tabular}

\begin{tabular}{|l|l|l|l|l|}
\hline $\mathrm{O}$ & $\mathrm{E}=\mathrm{R} . \mathrm{T} * \mathrm{C} . \mathrm{T} / \mathrm{G} . \mathrm{T}$ & {$[\mathrm{O}-\mathrm{E}]$} & {$[\mathrm{O}-\mathrm{E}]^{2}$} & {$[\mathrm{O}-\mathrm{E}]^{2} / \mathrm{E}$} \\
\hline 63 & $126^{*} 94 / 163=72.662$ & -9.66 & 93.31 & 1.28 \\
\hline 63 & $126 * 69 / 163=53.337$ & 9.66 & 93.31 & 1.74 \\
\hline 31 & $37 * 94 / 163=21.337$ & 9.66 & 93.31 & 4.37 \\
\hline 06 & $37 * 69 / 163=15.66$ & -9.66 & 93.31 & 5.95 \\
\hline & & & & 13.34 \\
\hline
\end{tabular}

$\mathrm{X}=[\mathrm{O}-\mathrm{E}]^{2} / \mathrm{E}$

Calculated value $=13.34$

Degree of freedom:

$$
\begin{aligned}
& \mathrm{V}=[\mathrm{r}-1][\mathrm{e}-1] \\
& \mathrm{V}=[2-1][2-1] \\
& \mathrm{V}=1
\end{aligned}
$$

Table value $=3.84($ constant value $)$

Calculated value $>$ table value

It is a significant

So alternative hypothesis accepted

\section{RESULTS}

The investigation demonstrates that $62 \%$ of respondents has happy with his workplace, and $21 \%$ of respondents has says impartial, and $12 \%$ of respondents has exceedingly fulfilled, and $3 \%$ of respondents has disappointed and $2 \%$ of respondents has very disappointed with his workplace.

2 . The investigation demonstrates that $52 \%$ of respondents has fulfilled in his working hours of the organization and $21 \%$ of respondents has profoundly fulfilled and, $21 \%$ of respondents says impartial, and $3 \%$ of respondents says disappointed and $3 \%$ of respondents says exceedingly disappointed with his working hours of the organization. [14], [16],[18]

3 . The investigation demonstrates that $37 \%$ of respondents has fulfilled of bottle office of the organization, and $24 \%$ of respondents has says impartial, and $22 \%$ of respondents says disappointed, and $15 \%$ of respondents says exceedingly fulfilled, and $2 \%$ of respondents has very disappointed of his flask office of the organization.

4. The investigation demonstrates that $30 \%$ of respondents has happy with his extra time remittances give by the organization, and $29 \%$ of respondents says impartial, and $29 \%$ of respondents says disappointment and $8 \%$ of respondents says very fulfillment, and $4 \%$ of respondents says profoundly disappointment with is additional time recompenses. [19], [21],[23]

5 . The investigation demonstrates that $70 \%$ of respondents has totally feeling their security in the organization and $30 \%$ of respondents has didn't feel the wellbeing in the organization

6. The investigation demonstrates that $100 \%$ of respondents says that the organization take care the ladies worker during the night move

7. The investigation demonstrates that $39 \%$ of respondents has very fulfilled in his therapeutic and emergency treatment office in the organization, and 39\% of respondents says fulfilled, and $19 \%$ of respondents says nonpartisan, and $2 \%$ of respondents says disappointed, and $1 \%$ of respondents says exceedingly disappointed in his medicinal and emergency treatment office in the organization

8 . The investigation demonstrates that $28 \%$ of respondents has gone to the wellbeing preparing program 1 time, and $24 \%$ of respondents went to 2 time, and $27 \%$ of respondents has gone to multiple occasions, and $21 \%$ of respondents have didn't go to any security preparing programs in the organization

9. The investigation demonstrates that $33 \%$ of respondents says awesome of 
his medical coverage and mishap advantages, and $31 \%$ of respondents says magnificent, and $22 \%$ of respondents says disappointed, and half of respondents says great in his medical coverage and mishap advantages to the representative

10. The examination demonstrates that $42 \%$ of respondents has fulfilled in his compensation and extra bundles, and $25 \%$ of respondents says disappointed, and $23 \%$ of respondents says very fulfilled, and $10 \%$ of respondents has says exceptionally disappointed in his pay and extra bundles.

11. The investigation demonstrates that $100 \%$ of respondents says the organization has give security shoes to each worker

12. The investigation demonstrates that $58 \%$ of respondents have fulfilled the appraisals of bathrooms, and $26 \%$ of respondents says exceptionally fulfilled, and $13 \%$ of respondents says unbiased, and $3 \%$ of respondents says disappointed the evaluations of bathrooms of the organization

13. The investigation demonstrates that $60 \%$ of respondents says the organization has give the augmentation in consistently, and $40 \%$ of respondents says not

14. The investigation demonstrates that $36 \%$ of respondents says in excess of three medical aid box stay with in the, $24 \%$ of respondents says three emergency treatment boxes, and $17 \%$ of respondents says just two medical aid box, and $23 \%$ of respondents says just a single medical aid box has kept in our office. [20], [22], [24]

15. The examination demonstrates that $56 \%$ of respondents has fulfilled of feel of the organization, and $28 \%$ of respondents says impartial, $10 \%$ of respondents says exceptionally fulfilled, and just $6 \%$ of respondents says disappointed of vibe of the organization

16. The investigation demonstrates that $48 \%$ of respondents has fulfilled of generally speaking fulfillment of worker welfare, $28 \%$ of respondents says profoundly fulfilled, and $21 \%$ of respondents says nonpartisan, and $3 \%$ of respondents says disappointed of by and large fulfillment of representative welfare.

\section{DISCUSSIONS}

The organization can guarantee that security preparing projects are directed for all representatives, since $21 \%$ of workers has didn't go to any wellbeing preparing programs. So the organization give the wellbeing preparing projects to all representatives for one of the month. [25], [27], [29]

- The executives needs to make a move in the container office in light of the fact that $22 \%$ of respondents state disappointed of flask office. So the organization has make a move to give quality and sound nourishment to the workers.

- The executives needs to make a move to improve the bathroom office and furthermore to clean the bathroom consistently, $5 \%$ of individuals were disappointed and over $20 \%$ of individuals were in impartial in is fulfillment of bathroom offices. [26], [28], [30]

- The organization could give all the wellbeing shoes and wears to every one of the workers including the house keepings.

- The board needs to make a move to give the mishap advantages to representative on the grounds that $25 \%$ of individuals were disappointed in mishap benefits.

- The board needs to improve the therapeutic and emergency treatment office.

- The board of has likewise improve the feeling of the organization.

- The board could give the cafeteria to unwinding of worker throughout the break time.

\section{CONCLUSION}

The investigation entitled A STUDY ON EMPLOYEE WELFARE MOTIVE IN SAR WORLDWIDE LOGISTICS Pvt Lmt plans to discover the worker mindfulness and fulfillment level with different welfare plans and wellbeing wears are given by the organization.

In light of the examination $90 \%$ of worker has disclosed to SAR WORLDWIDE LOGISTICS organization has given the wellbeing wears to the representative. Representative has completely fulfilled in restorative examination consistently in the organization. Organization give welfare offices to their representatives to keep their inspiration level high. [31],[33] And furthermore give numerous such statutory and non-statutory things approaches to keep up palatable degree of the worker. At long last the investigation of end that the workers are happy with the present welfare offices and security offices in the organization.

\section{REFERENCES}

1) BharthVajan R., Ramachandran S.,Psychographic dimensions of training,2016,International Journal of Pharmacy and Technology,V-8,I-4,P-23727-23729

2) Balakrishnan P., Bharthvajan R.,A study on human resource planning in hospitals in Chennai City,2014,International Journal of Applied Engineering Research,V-9,I-22,P-7503-7507

3) Priyadarsini P., Bharthvajan R.,Role of emotional intelligence training programme in reducing the stress of the nurses,2014,International Journal of Applied Engineering Research,V-9,I-22,P-7411-7421

4) Kerinab Beenu G., Bharthvajan R.,Empirical analysis on the cosmetic buying behavior of young women in South India,2014,International Journal of Applied Engineering Research,V-9,I-22,P-7361-7366

5) Balakrishnan P., Bharthvajan R.,Whistling in the wind,2014,International Journal of Applied Engineering Research,V-9,I-22,P-7586-7593

6) Krishnan B., Peter M.,Health hazards of Indian Bpo employee-an alarming issue,2014,International Journal of Applied Engineering Research,V-9,I-22,P-7336-7341

7) Kerinab Beenu G.H., Peter M.,Role of insurance in economic development,2014,International Journal of Applied Engineering Research,V-9,I-22,P-7532-7539

8) Balakrishnan P., Peter M., Priyadarsini P.,Efficiency of safety measures for wellbeing of employees in manufacturing industry,2014,International Journal of Applied Engineering Research,V-9,I-22,P-7376-7382

9) Anbarasi M., Praveen Kumar S.,Online sales promotions of herbal products and its effectiveness towards tanisha.com,2019, Indian Journal of Public Health Research and Development,V-10,I-1,P-195-200

10) Anbarasi M., Praveen Kumar S.,Various online marketing and promotions strategies to improve the validation towards the organic products in the pharmaceutical sectors, 2019,Indian Journal of Public Health Research and Development, V-10,I-1,P-263-269

11) Loganathan R., Praveen Kumar S.,Grievance handling a key factor for solving issues of employees in an

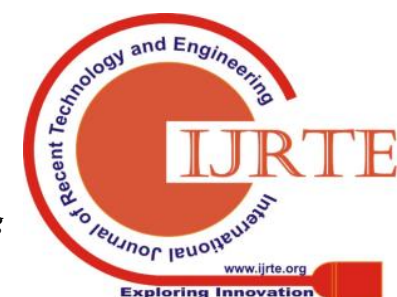


organization,2014,International Journal of Applied Engineering Research,V-9,I-22,P-7483-7491

12) Loganathan R., Praveen Kumar S.,Study on preference of private label brands in super and Hypermarkets,2014,International Journal of Applied Engineering Research,V-9,I-22,P-7327-7335

13) Smitha M., Praveen Kumar S.,Understanding stress and its managementamong the nurses in Chennai city,2014,International Journal of Applied Engineering Research,V-9,I-22,P-7560-7565

14) Kerinab Beenu G.H., Praveen Kumar S.,A study on the investmen behavior of Chennai investors in mutual fund schemes,2014,International Journal of Applied Engineering Research,V-9,I-22,P-7520-7525

15) Loganathan R., Praveen Kumar S.,Retention strategies key for organizational productivity,2014,International Journal of Applied Engineering Research,V-9,I-22,P-7443-7447

16) Pavithra J., Ganesan M., Brindha G.,State wise analysis of microfinance sector in India,2016,International Journal of Pharmacy and Technology,V-8,I-4,P-23417-23432

17) Pavithra J., Ganesan M.,A comparative study on microfinance in India and abroad,2016,International Journal of Applied Business and Economic Research,V-14,I-8,P-5471-5476

18) Pavithra J., Ganesan M.,A study on awareness and impact of micro-financial schemes,2016,International Journal of Applied Business and Economic Research,V-14,I-8,P-5449-5460

19) Senthilmurugan P., Pavithra J.,Consumer preference towards organised retailing with reference to Big Bazaar,2014,International Journal of Applied Engineering Research,V-9,I-22,P-7469-7475

20) Senthilmurugan P., Pavithra J.,Implication of social media marketing in growing healthcare industry,2014,International Journal of Applied Engineering Research,V-9,I-22,P-7448-7456

21) Loganathan R., Pavithra J.,Consumer perception towards private label brand over other brands in super markets and hypermarkets,2014,International Journal of Applied Engineering Research,V-9,I-22,P-7355-7360

22) Kerinab Beenu G., Pavithra J.,Tradeâ€"off between liquidity and profitability in logistics industry,2014,International Journal of Applied Engineering Research,V-9,I-22,P-7398-7401

23) Kerinab Beenu G., Pavithra J.,A study on the prospective consumerâ€ $\mathbf{T M}_{\mathbf{S}}$ perception towards utility cars in Chennai city,2014,International Journal of Applied Engineering Research,V-9,I-22,P-7526-7531

24) Pavithra J., Dilli Babu P., Ambuli T.V.,A study on budgetary control at Maruti Service Masters, Chennai,2014,International Journal of Applied Business and Economic Research,V-12,I-2,P-151-161

25) Pavithra J., Dilli Babu P., Ambuli T.V.,A study on customer satisfaction of retro Garments Pvt Ltd, Chennai,2014,International Journal of Applied Business and Economic Research,V-12,I-2,P-381-391

26) Kerinab Beenu G.H., Pavithra J., Senthilmurugan P.,A study on the influence of promotional activities for TATA ARIA among consumers in Chennai,2014,International Journal of Applied Engineering Research,V-9,I-22,P-7572-7578

27) Vijayaragavan S.P.,An investigative expert that's general FBG sensors,International Journal of Mechanical Engineering and Technology, V-8,I-8,PP-1500-1505,Y-2017

28) Vijayaragavan S.P.,Equalization routing protocol for $\mathrm{Wi}-\mathrm{Fi}$ sensor strategy,International Journal of Mechanical Engineering and Technology,V-8,I-8,PP-1662-1666,Y-2017

29) Karthik B., Kiran Kumar T.V.U., Vijayaragavan P., Bharath Kumaran E.,Design of a digital PLL using 0.35 $\hat{\mathrm{I}}^{1 / 4 \mathrm{~m}}$ CMOS technology,Middle East Journal of Scientific Research,V-18,I-12,PP-1803-1806,Y-2013

30) Kanniga E., Selvaramarathnam K., Sundararajan M.,Kandigital bike operating system,Middle - East Journal of Scientific Research,V

31) Jasmin M., Vigneshwaran T., Beulah Hemalatha S.,Design of power aware on chip embedded memory based FSM encoding in FPGA,International Journal of Applied Engineering Research,V-10,I-2,PP-4487-4496,Y-2015

32) Jasmin M.,Optimization techniques for low power VLSI circuits,Middle East Journal of Scientific Research,V-20,I-9,PP-1082-1087,Y-2014

33) Jasmin M., Vigneswaran T.,Fuzzy controller for error control of on - Chip communication,2017 International Conference on Algorithms, Methodology, Models and Applications in Emerging Technologies, ICAMMAET 2017,V-2017-January,I-,PP-1-5,Y-2017

\section{AUTHORS PROFILE}

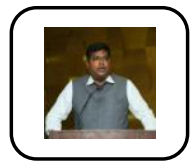

Dr. S. Praveen Kumar Professor, Department of MBA, Bharath Institute of Higher Education and Research, Chennai, India.

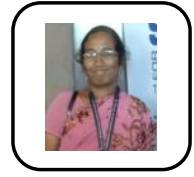

Ms. J. Pavithra Assistant Professor, Department of MBA, Bharath Institute of Higher Education and Research, Chennai, India.

S. Krupa Sharon Nishitha Student, Department of MBA, Bharath Institute of Higher Education and Research, Chennai, India. 